\title{
Effects of Integrated Use of Calliandra calothyrsus and Maize Stover with Urea on Maize Yield Components under Striga Infestation in Western Kenya
}

\author{
Nyambati R. O. ${ }^{1, *}$, Odhiambo G. D. ${ }^{2}$, Serrem C. K. ${ }^{3}$, Othieno C. O. ${ }^{3}$, Mairura F. S. ${ }^{4}$ \\ ${ }^{1}$ Kenya Forestry Research Institute, Kenya \\ ${ }^{2}$ Department of Applied Plant Science, Maseno University, Kenya \\ ${ }^{3}$ Department of Soil Science, University of Eldoret, Kenya \\ ${ }^{4}$ Department of Land and Water Management, University of Embu, Kenya
}

Received November 20, 2019; Revised May 12, 2020; Accepted July 1, 2020

\section{Cite This Paper in the following Citation Styles}

(a): [1] Nyambati R. O., Odhiambo G. D., Serrem C. K., Othieno C. O., Mairura F. S. , "Effects of Integrated Use of Calliandra calothyrsus and Maize Stover with Urea on Maize Yield Components under Striga Infestation in Western Kenya," Universal Journal of Agricultural Research, Vol. 8, No. 5, pp. 165 - 172, 2020. DOI: 10.13189/ujar.2020.080504.

(b): Nyambati R. O., Odhiambo G. D., Serrem C. K., Othieno C. O., Mairura F. S. (2020). Effects of Integrated Use of Calliandra calothyrsus and Maize Stover with Urea on Maize Yield Components under Striga Infestation in Western Kenya. Universal Journal of Agricultural Research, 8(5), 165 - 172. DOI: 10.13189/ujar.2020.080504.

Copyright@2020 by authors, all rights reserved. Authors agree that this article remains permanently open access under the terms of the Creative Commons Attribution License 4.0 International License

\begin{abstract}
The effect of integrated use of Calliandra or maize stover with urea on Striga infestation and maize yield components was assessed in a field experiment carried out for five consecutive seasons on a clay loam Ferralsol in western Kenya. Urea and Calliandra or maize stover were combined to supply $\mathrm{N}$ at $75 \mathrm{~kg} \mathrm{ha}^{-1}$ from both sources in 0:0, 100:0, 80:20, 60:40, 40:60, 20:80, 0:100 ratios. A randomized complete block design (RCBD) with 12 treatments replicated four times was used with maize hybrid (WS 502) as a test crop. All the three ear traits (ears per plant, ear length, and ear diameter), kernels per row and grain yields were significantly higher under Calliandra (45 $\left.\mathrm{kg} \mathrm{N} \mathrm{ha}{ }^{-1}\right)$ combined with urea $\left(30 \mathrm{~kg} \mathrm{~N} \mathrm{ha}{ }^{-1}\right)$ and Calliandra $\left(30 \mathrm{Kg} \mathrm{N} \mathrm{ha}^{-1}\right)$ combined with urea $(45 \mathrm{~kg} \mathrm{~N}$ $\mathrm{ha}^{-1}$ ) or maize stover $\left(45 \mathrm{~kg} \mathrm{~N} \mathrm{ha}^{-1}\right)$ combined with urea (30 $\left.\mathrm{kg} \mathrm{N} \mathrm{ha}{ }^{-1}\right)$ and maize stover $\left(30 \mathrm{~kg} \mathrm{~N} \mathrm{ha}^{-1}\right)$ combined with urea (45 kg N/ha ${ }^{-1}$ ). Number of ears per plant was a major yield component and accounted for $\left(\mathrm{R}^{2}=0.74\right)$ of the variation in grain yield under Striga. Stepwise regression analysis showed ears per plant to be the most important yield component under Striga infestation $\left(\mathrm{R}^{2}=0.58\right)$ followed by kernels per row $\left(\mathrm{R}^{2}=0.38\right)$.
\end{abstract}

Keywords Maize Yield Components, Striga, Calliandra, Maize Stover, Urea

\section{Introduction}

Striga, commonly known as witchweed, is the most economically important parasitic weed seed plant in the world. It is a genus of 28 species of parasitic plants that occur naturally in parts of Africa, Asia and Australia. The genus is now classified in the family of Orobanchaceae although it was earlier placed in the family Scrophulariaceae [1]. Four species of the parasite cause economic losses in cereal crops and these are $S$. hermonthica (Del.) benth., S. asiatica (L.) kuntze, S. aspera (Willd.) Benth. And S. forbesii Benth. Among these, $S$. hermonthica is the most widespread and causes the greatest losses.

Striga hermonthica has the potential to threaten food security in many countries and is particularly significant in Africa [2]. It decimates maize which is the main staple food crop for close to 300 million people in Africa [3,4] with yield loss estimated at 10 million tons grain worth \$ US 7 billion $[5,6]$.

Striga infests about 212,000 hectares (about 15\% of the arable land) in the Lake Victoria basin of Kenya [7], 
causing yield losses of between 30-50\% although losses of up to $100 \%$ have been reported [8]. Results of a survey on 83 farms in Western Kenya revealed that $73 \%$ of the farms are severely infected with S. hermonthica [9]. The potential maize yield in Western Kenya is 4-5 ton/ha [10] with the average yield loss attributed to Striga infection being 1.15 tons per hectare for maize [11]. Striga weeds are known to cause crop yield losses of between $20-100 \%$ for maize [12, $13]$ and $20-50 \%$ in sorghum $[14,13]$ although $100 \%$ yield loss is not uncommon. The build-up of Striga hermonthica (Del) Benth (witchweed) is associated with declining soil fertility resulting from continuous-intensive cropping without adequate fertilizer inputs [15, 10], a common phenomenon in densely populated farming systems of western Kenya [16]. This profound yield loss necessitates the identification of management systems that increase and maintain adequate levels of soil fertility while at the same time reducing the Striga weed infestation. Integrated Soil Fertility Management (ISFM) has been demonstrated as a strategy that can address the complexities and peculiarities of soil fertility management on smallholder farms, help low resource endowed farmers mitigate problems of poverty and food insecurity by improving the quantity of food, income and resilience of soil productive capacity [17].

Yield a quantitative trait is functionally related to yield components. Information on the effect of integrated soil fertility management on maize yield components under Striga infestation could be useful to physiologists, modelers and agronomists. Research evidence regarding organic resource types and fertilizer application effects on Striga and maize performance under small-holder farming conditions is insufficient and fragmentary in Western Kenya and multiple agro-ecozones infested with Striga. This information could provide a vehicle for increasing efficiency of input and resource use by the staple food security crop, reducing the risks farmers face in using purchased inputs and encourage the adoption of improved technologies. The objective of this study was therefore to assess the effect of applying Calliandra and maize stover with urea on maize yield components under Striga infestation on small-scale farming conditions in western Kenya.

\section{Materials and Methods}

\subsection{Experimental Site}

This study was conducted at Nyabeda ( $\mathrm{N}^{\circ} 08^{\prime}, \mathrm{E} 34^{\circ}$ 24 ') in Siaya District of western Kenya. The area is classified as midlands (LM 2) with an altitude of approximately $1330 \mathrm{~m}$ above sea level [18]. Rainfall is bimodal, allowing two cropping seasons a year with the long rains starting from March ending in July and the short rains starting from August ending in November, with a mean annual of $1800 \mathrm{~mm}$. Mean annual temperature ranges between $22^{\circ} \mathrm{C}$ and $24^{\circ} \mathrm{C}$. The soils are classified as
Ferralsols/Nitisols (Kandiudalfic Eutrudox), clayey, reddish, deep and well drained [18]. The soils chemical and physical properties sampled from the top $0-15 \mathrm{~cm}$ had the following characteristics; $\mathrm{pH}=4.9$, total soil organic carbon $2.33 \mathrm{~kg}^{-1}$, total soil $\mathrm{N}=0.23 \mathrm{~g} \mathrm{~kg}^{-1}$, Olsen $\mathrm{P}=2.75 \mathrm{mg} \mathrm{kg}^{-1}$, exchangeable $\mathrm{Ca}=7.95 \mathrm{cmol}_{\mathrm{c}} \mathrm{kg}^{-1}$, exchangeable $\mathrm{Mg}=4.78$ $\mathrm{cmol}_{\mathrm{C}} \mathrm{kg}^{-1}$, exchangeable potassium $=0.05 \mathrm{cmol}_{\mathrm{c}} \mathrm{kg}^{-1}$, exchangeable $\mathrm{Na}=0.40 \mathrm{cmol}_{\mathrm{c}} \mathrm{kg}^{-1}$, clay $=23 \%$, silt $=14 \%$ and sand $=63 \%$.

\subsection{Experimental Design, Establishment and Management}

The trial had 12 treatments comprising of two plant residues applied solely, or in combination with inorganic fertilizer (urea), sole inorganic fertilizer and a control. The plant residues were maize stover and Calliandra calothyrsus (Table 1). The experiment was laid out in a randomized complete block design (RCBD) with twelve treatments replicated four times. A substitution type of experiment was used whereby the total $\mathrm{N}$ rate was fixed at the recommended rate of $75 \mathrm{~kg} \mathrm{~N}^{-1}{ }^{-1}$ for maize in the study area. Treatments were combined in the following ratios i.e. $0: 0,100: 0,80: 20,60: 40,40: 60,20: 80$, and $0: 100$ so as to

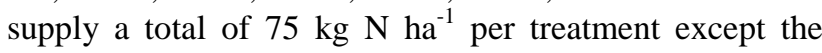
control i.e. treatment 0:0 where no $\mathrm{N}$ inputs were applied. Maize stover was obtained from neighbouring farms and Calliandra from an established demonstration plot within the area. At the beginning of every planting season, the plant residues were weighed, chopped and incorporated into the soil at a depth of $15 \mathrm{~cm}$ during land preparation. Fertilizer $\mathrm{N}$ in the form of urea was applied in splits with $33.3 \%$ of corresponding rates applied at planting and the rest (66.6\%) six weeks later. Phosphorus (P) and potassium (K) were uniformly applied to all plots at the rate of $40 \mathrm{~kg} P$ and $20 \mathrm{~kg} \mathrm{~K} \mathrm{ha}^{-1}$ as triple super phosphate and muriate of potash, respectively at the beginning of each season. One day after treatment application, a commercial maize variety WH 502, commonly grown by farmers in the area, was planted as a test crop at a spacing of $75 \mathrm{~cm}$ and $25 \mathrm{~cm}$ in inter and intra row spacing, respectively. Other agronomic procedures for maize production were appropriately followed after planting. Maize was harvested at physiological maturity and grain yield and yield components determined.

\subsection{Striga Count and Collection in the Field}

Data were collected on Striga infestation in all the plots. Striga shoots that emerged in the field were counted in the six middle rows (net plot area $27 \mathrm{~m}^{2}$ ) at 2-week intervals starting from the day of Striga appearance and the maximum number of shoots recorded in each plot was recorded as Striga infestation. Striga emergence data were converted to the number of Striga plants $\mathrm{m}^{-2}$. Data on maize damage score was based on a scale of 1 to 9 (1=normal plant growth, no visible damage; $9=$ severe damage or death) at 10 weeks after planting of maize [19]. 
Table 1. Description of treatments used in the field trial

\begin{tabular}{ccccc}
\hline Treatment & Types of plant residues & $\begin{array}{c}\mathrm{N} \text { from in plant } \\
\text { residues }\left[\mathrm{kg} \mathrm{N} \mathrm{ha}{ }^{-1}\right]\end{array}$ & $\begin{array}{c}\mathrm{N} \text { in form of urea }[\mathrm{kg} \\
\left.\mathrm{N} \mathrm{ha}^{-1}\right]\end{array}$ & Total N $\left[\mathrm{kg} \mathrm{N} \mathrm{ha}^{-1}\right]$ \\
\hline 1 & None & $0(0 \%)$ & $0(0 \%)$ & 0 \\
2 & Calliandra & $75(100 \%)$ & $0(0 \%)$ & 75 \\
3 & Calliandra & $60(80 \%)$ & $15(20 \%)$ & 75 \\
4 & Calliandra & $45(60 \%)$ & $30(40 \%)$ & 75 \\
5 & Calliandra & $30(40 \%)$ & $45(60 \%)$ & 75 \\
6 & Calliandra & $15(20 \%)$ & $60(80 \%)$ & 75 \\
7 & Maize stover & $75(100 \%)$ & $0(0 \%)$ & 75 \\
8 & Maize stover & $60(80 \%)$ & $15(20 \%)$ & 75 \\
9 & Maize stover & $45(60 \%)$ & $30(40 \%)$ & 75 \\
10 & Maize stover & $30(40 \%)$ & $45(60 \%)$ & 75 \\
\hline
\end{tabular}

Table 2. Striga rating scale interpretations

\begin{tabular}{|c|c|}
\hline Rating & \multicolumn{1}{c|}{ Interpretation } \\
\hline 1 & Normal plant growth, no visible symptoms, \\
\hline 2 & Mild leaf blotching with some purplish-brown necrotic spots \\
\hline 3 & Extensive blotching and mild wilting. Slight but noticeable stunting and reduction in ear and tassel size \\
\hline 4 & Extensive leaf blotching, wilting and some scorching. Moderate stunting, ear and tassel size reduction \\
\hline 5 & $\begin{array}{l}\text { Extensive leaf blotching with mostly frays necrotic spots. Some stunting and reduction in stem diameter, ear size and } \\
\text { tassel size. }\end{array}$ \\
\hline 7 & $\begin{array}{l}\text { Definite leaf scorching, with gray necrotic spots, and leaf wilting and rolling. Severe stunting and reduction in stem } \\
\text { diameter, ear size, and tassel size, often causing stalk lodging, brittleness, and husk opening at a late-growing stage. }\end{array}$ \\
\hline 8 & $\begin{array}{l}\text { Definite leaf scorching with extensive gray necrotic spots. Conspicuous stunting, leaf wilting, rolling, severe stalk } \\
\text { lodging, and brittleness. Reduction in stem diameter, ear size and tassel size. }\end{array}$ \\
\hline 9 & Complete scorching of all leaves, causing premature death or collapse of host plant and no ear formation \\
\hline
\end{tabular}

\subsection{Statistical Analysis}

Analysis of variance (ANOVA) and mean comparisons on the data to determine the effects of treatments on Striga incidence and maize yield components were done using Genstat 10 for windows (Release 8.1). Striga emergence data were transformed to $\log _{10}(n+1)$ before statistical analysis. Average values of the respective traits in each season were used to generate correlation coefficients between grain yields and yield components. Stepwise regression analysis was employed to determine the most important yield components under Striga. Mention of statistical significance refers to $\mathrm{P}<0.05$ unless otherwise stated. Significant means were separated using the LSD post-hoc tests.

\section{Results}

\subsection{Maize Damage and Striga Emergence}

Seasonal trends in Striga incidence over the period of study are summarized in Table 3 . There were highly significant $(p<0.001)$ differences between seasons. The highest Striga densities (115 plants $\mathrm{m}^{-2}$ ) were observed in sole maize stover $\left(75 \mathrm{~kg} \mathrm{~N} \mathrm{ha}^{-1}\right)$ and maize stover applied at
$60 \mathrm{~kg} \mathrm{~N} \mathrm{ha}{ }^{-1}$ combined with urea at $\left.15 \mathrm{~kg} \mathrm{~N} \mathrm{ha}^{-1}\right)(114$ plants $\mathrm{m}^{-2}$ ). The two treatments had significantly higher Striga counts than all other treatments. Averaged over five seasons, Striga density was higher in the control and in treatments receiving more than $80 \%$ of $\mathrm{N}$ from maize stover (Table 3). In 2007 and 2008, Striga emergence was higher during long rains than the short rain seasons. The season by treatment interaction on Striga intensity was not significant $(\mathrm{p}=0.65)$.

There were highly significant differences $(p<0.001)$ between treatments in damage scores (Table 3 ). The highest damage score (6.6) was recorded in the control while the lowest (2.4) was recorded under Calliandra (45 $\mathrm{kg} \mathrm{N} \mathrm{ha}{ }^{-1}$ ) combined with urea (30 kg N ha $\left.{ }^{-1}\right)$. Damage scores ranks of the maize under different treatment corresponded to the level of soil mineral nitrogen in the soil.

\subsection{Effect of Treatments on Maize Grain Yield Components}

\subsubsection{Ear traits}

The effect of treatments and seasons on the number of ears per plant, ear length, and ear diameter were highly significant $(P<0.001)$ (Table 4$)$. All the three ear traits (ears 
per plant, ear length, and ears diameter) were significantly higher under Calliandra (45 kg N ha ${ }^{-1}$ ) combined with urea (30 kg N ha ${ }^{-1}$ ) and Calliandra (30 Kg N ha ${ }^{-1}$ ) combined with urea (45 $\mathrm{kg} \mathrm{N} \mathrm{ha}^{-1}$ ) or maize stover (45 $\mathrm{kg} \mathrm{N} \mathrm{ha}^{-1}$ ) combined with urea (30 Kg N ha ${ }^{-1}$ ) and maize stover at (30 $\mathrm{Kg} \mathrm{N} \mathrm{ha}^{-1}$ ) combined with urea (45 $\mathrm{Kg} \mathrm{N} \mathrm{ha}^{-1}$ ) compared to sole maize stover and the control. Ears per plant were highest (0.82), under maize stover (30 kg N ha ${ }^{-1}$ ) combined with urea (45 $\mathrm{kg} \mathrm{N} \mathrm{ha}^{-1}$ ) while the lowest ears per plant (0.56) were recorded in the control. Ear length and ear diameter followed the same trend. Sole maize stover had the lowest ear diameter (0.39).

Table 3. Effect of combined use organic residues and urea on Striga counts $\left(\mathrm{m}^{2}\right)$ at Nyabeda, western Kenya (values in brackets are transformed values of Striga incidence $\log _{10}(\mathrm{x}+1)$

\begin{tabular}{|c|c|c|c|c|c|c|}
\hline \multirow{3}{*}{ Treatments } & \multicolumn{5}{|c|}{ Seasons } & \multirow{2}{*}{$\begin{array}{c}\text { Striga } \\
\text { tolerance } \\
\text { score }\end{array}$} \\
\hline & 2007 LR & 2007 SR & 2008 LR & 2008 SR & 2009 LR & \\
\hline & \multicolumn{5}{|c|}{ Plants $\mathrm{m}^{-2}$} & \\
\hline Control & $118(2.07)$ & 57 (1.76) & 19 (1.28) & $4(0.60)$ & $11(1.04)$ & 2.8 \\
\hline $75 \mathrm{CC}+0 \mathrm{U}$ & $146(2.16)$ & 45 (1.65) & $13(1.11)$ & $4(0.60)$ & $9(0.95)$ & 3.6 \\
\hline $60 \mathrm{CC}+15 \mathrm{U}$ & $128(2.11)$ & 65 (1.81) & $16(1.20)$ & $7(0.85)$ & $14(1.15)$ & 2.4 \\
\hline $45 C C+30 U$ & 117 (2.07) & $29(1.46)$ & $10(1.0)$ & $4(0.60)$ & $12(1.08)$ & 2.6 \\
\hline $30 \mathrm{CC}+45 \mathrm{U}$ & $100(2.0)$ & 55 (1.74) & 12 (1.08) & $3(0.48)$ & $11(1.04)$ & 4.1 \\
\hline $15 \mathrm{CC}+60 \mathrm{U}$ & $105(2.02)$ & 38 (1.58) & 13 (1.11) & $4(0.60)$ & $8(0.90)$ & 4.5 \\
\hline $75 \mathrm{MS}+0 \mathrm{U}$ & 89 (1.95) & 115 (2.06) & 15 (1.18) & $3(0.48)$ & 15 (1.18) & 4.7 \\
\hline $60 \mathrm{MS}+15 \mathrm{U}$ & $141(2.15)$ & $114(2.06)$ & $16(1.20)$ & $7(0.85)$ & 15 (1.18) & 3.0 \\
\hline $45 \mathrm{MS}+30 \mathrm{U}$ & 44 (1.64) & 49 (1.69) & $6(0.78)$ & $3(0.48)$ & $9(0.95)$ & 2.6 \\
\hline $30 \mathrm{MS}+45 \mathrm{U}$ & 68 (1.83) & 37 (1.57) & $9(0.95)$ & $5(0.70)$ & $8(0.90)$ & 3.4 \\
\hline $15 \mathrm{MS}+60 \mathrm{U}$ & 154 (2.19) & $40(1.60)$ & $8(0.90)$ & $4(0.60)$ & $14(1.15)$ & 3.9 \\
\hline $75 \mathrm{U}$ & $126(2.10)$ & 49 (1.69) & $11(1.04)$ & $4(0.60)$ & $9(0.95)$ & 3.7 \\
\hline Mean & 111(1.96)a & 58(1.68)b & 13(1.01)c & $4(0.67) d$ & 11(1.01)c & \\
\hline $\mathrm{P}$ treat & $0.44(0.18)$ & $<0.001(0.003)$ & $0.74(0.15)$ & $0.59(0.76)$ & $0.57(0.35)$ & $<0.001$ \\
\hline $\mathrm{LSD}_{0.05}$ & NS & $38(0.28)$ & NS & NS & NS & \\
\hline $\mathrm{CV}$ & (42) 8.2 & (38)8.8 & (25)9.3 & (30)15.1 & (54)19.8 & 20 \\
\hline LSD treat & $<0.001$ & & & & & 1.62 \\
\hline $\mathrm{P}_{\mathrm{r}}$ (season) & $<0.001$ & & & & & \\
\hline $\begin{array}{c}\text { Pr (treat } x \\
\text { season) }\end{array}$ & 0.65 & & & & & NS \\
\hline
\end{tabular}

'LR', 'SR', mean 'long rainy season', and 'short rain season', respectively, values in brackets are transformed values of Striga incidence log ${ }_{10}(\mathrm{n}+1)$, $\mathrm{CC}=$ Calliandra, $\mathrm{MS}=$ maize stover, $\mathrm{U}=\mathrm{urea}, \mathrm{NS}=$ non-significant. 
Table 4. Mean grain yields and yield components of maize under Striga infestation averaged over five seasons at Nyabeda

\begin{tabular}{|c|c|c|c|c|c|c|c|}
\hline Treatment & $\begin{array}{l}\text { Ears/ } \\
\text { plant }\end{array}$ & $\begin{array}{c}\text { Ear } \\
\text { length } \\
(\mathrm{cm}) \\
\end{array}$ & $\begin{array}{c}\text { Ear } \\
\text { diameter } \\
(\mathrm{cm}) \\
\end{array}$ & $\begin{array}{c}\text { Kernel } \\
\text { rows }\end{array}$ & $\begin{array}{c}\text { Kernels/ } \\
\text { row }\end{array}$ & $\begin{array}{c}100 \mathrm{wt} \\
(\mathrm{g})\end{array}$ & $\begin{array}{c}\text { Grain } \\
\text { yield } \\
\text { (g/plant) }\end{array}$ \\
\hline Control & 0.56 & 13.3 & 4.0 & 13.0 & 26.9 & 24.5 & 24.0 \\
\hline $75 \mathrm{CC}+0 \mathrm{U}$ & 0.77 & 15.1 & 4.2 & 13.2 & 27.5 & 27.1 & 45.0 \\
\hline $60 \mathrm{CC}+15 \mathrm{U}$ & 0.64 & 14.6 & 4.3 & 13.4 & 30.8 & 25.3 & 37.1 \\
\hline $45 \mathrm{CC}+30 \mathrm{U}$ & 0.79 & 15.4 & 4.2 & 13.1 & 33.4 & 25.8 & 54.0 \\
\hline $30 \mathrm{CC}+45 \mathrm{U}$ & 0.79 & 15.4 & 4.3 & 13.7 & 32.2 & 25.6 & 48.5 \\
\hline $15 \mathrm{CC}+60 \mathrm{U}$ & 0.76 & 14.6 & 4.2 & 13.4 & 31.7 & 26.2 & 41.9 \\
\hline $75 \mathrm{MS}+0 \mathrm{U}$ & 0.64 & 13.3 & 3.9 & 12.3 & 27.4 & 22.9 & 30.5 \\
\hline $60 \mathrm{MS}+15 \mathrm{U}$ & 0.71 & 14.2 & 4.1 & 13.4 & 30.1 & 23.9 & 37.1 \\
\hline $45 \mathrm{MS}+30 \mathrm{U}$ & 0.80 & 15.1 & 4.3 & 13.1 & 32.6 & 25.1 & 50.0 \\
\hline $30 \mathrm{MS}+45 \mathrm{U}$ & 0.82 & 16.1 & 4.4 & 13.2 & 35.0 & 28.7 & 59.9 \\
\hline $15 \mathrm{MS}+60 \mathrm{U}$ & 0.76 & 15.2 & 4.3 & 12.9 & 33.4 & 27.1 & 45.4 \\
\hline $75 \mathrm{U}$ & 0.70 & 14.5 & 4.2 & 12.9 & 30.6 & 25.9 & 39.7 \\
\hline Mean & 0.73 & 14.7 & 4.2 & 13.1 & 31.4 & 25.7 & 42.8 \\
\hline P (treat) & $<0.001$ & $<0.001$ & $<0.001$ & $<0.05$ & $<0.001$ & $<0.001$ & $<0.001$ \\
\hline $\mathrm{P}$ (season) & $<0.001$ & $<0.001$ & $<0.001$ & $<0.001$ & $<0.001$ & $<0.001$ & $<0.001$ \\
\hline $\mathrm{P}$ (treat $\mathrm{x}$ season) & 0.184 & NS & 0.135 & 0.29 & 0.277 & NS & 0.002 \\
\hline LSD (treat) & 0.108 & 1.14 & 0.16 & 0.72 & 3.27 & 2.15 & 11.0 \\
\hline LSD (season) & 0.06 & 0.66 & 0.09 & 0.42 & 1.89 & 1.24 & 6.37 \\
\hline $\begin{array}{c}\text { LSD (treat } x \\
\text { season) }\end{array}$ & 0.21 & 2.28 & 0.31 & 1.44 & 6.55 & 4.30 & 22.05 \\
\hline $\mathrm{CV}$ & 7.0 & 3.0 & 2.5 & 2.2 & 3.7 & 1.5 & 13.3 \\
\hline
\end{tabular}

Table 5. Correlation coefficient (r) between grain yields and yield components

\begin{tabular}{ccccccc}
\hline \multirow{2}{*}{ Yield component } & \multicolumn{5}{c}{ Season } & \multirow{2}{*}{ Overall } \\
\cline { 2 - 5 } & LR2007 & SR2007 & LR2008 & SR2008 & LR2009 & $0.76^{* * *}$ \\
\hline Ears per plant & $0.80^{* * *}$ & $0.60^{* * *}$ & $0.84^{* * *}$ & $0.55^{* * *}$ & $0.38^{* *}$ & 0.37 \\
Ear length & $0.75^{* * *}$ & $0.38^{*}$ & $0.43^{* *}$ & $0.28^{*}$ & $0.55^{* * *}$ & $0.39^{* * *}$ \\
Ear diameter & $0.46^{* * *}$ & $0.40^{* *}$ & $0.52^{* * *}$ & $0.35^{*}$ & $0.038^{* *}$ & 0.48 \\
Kernels/row & 0.05 & $0.45^{* *}$ & $0.37^{* *}$ & $0.47^{* *}$ & $0.51^{* * *}$ & $0.62^{* * *}$ \\
Kernel rows & $0.68^{* * *}$ & 0.20 & $0.36^{*}$ & 0.16 & $0.50^{* * *}$ & $0.37^{* *}$ \\
\hline
\end{tabular}

*** and $* * *$ Significant at $0.1,0.05,0.01$ and 0.001 probability levels, respectively

\subsection{Kernel Traits and Grain Yields}

\subsubsection{Number of grains per row}

There were highly significant differences $(\mathrm{p}<0.001)$ between seasons and treatments in kernels per row (Table 4). The highest kernels per row (35.0) was recorded under maize stover $\left(30 \mathrm{~kg} \mathrm{~N} \mathrm{ha}^{-1}\right)$ combined with urea at $(45 \mathrm{~kg} \mathrm{~N}$ $\mathrm{ha}^{-1}$ ) while the lowest (26.9) was recorded in the control.

\subsection{Grain Yield}

Grain yields and 100-grain weight were optimized at Calliandra $\left(45 \mathrm{~kg} \mathrm{~N} \mathrm{ha}^{-1}\right)$ combined with urea $\left(30 \mathrm{~kg} \mathrm{~N} \mathrm{ha}^{-1}\right)$ and Calliandra (30 Kg N ha $\left.{ }^{-1}\right)$ combined with urea $(45 \mathrm{~kg}$ $\mathrm{N} \mathrm{ha}^{-1}$ ) or maize stover ( $45 \mathrm{~kg} \mathrm{~N} \mathrm{ha}^{-1}$ ) combined with urea
(30 kg N ha $\left.{ }^{-1}\right)$ and maize stover at $\left(30 \mathrm{~kg} \mathrm{~N} \mathrm{ha}^{-1}\right)$ combined with urea $\left(45 \mathrm{Kg} \mathrm{N} \mathrm{ha}^{-1}\right)$. Treatments with sole maize stover and the control had the lowest maize yields.

\subsection{Relationship between Maize Grain Yield and Yield Components}

All yield components except ear length and kernel rows were significantly $(p<0.1-0.001)$ correlated with grain yields (Table 5). However, the degree of association for the various yield components was dependent on season. Correlations were strong in the long rainy seasons than the short rainy seasons. This may be attributed to higher stress levels (Striga, nutrient and moisture) in the short rainy seasons. Ears per plant showed the highest correlation with 
grain yield $(r=0.76, \mathrm{p}<0.001)$.

Table 6. Regression equations relating yield components (X) to grain yield (Y) under Striga and coefficients of determination

\begin{tabular}{cccc}
\hline \multicolumn{4}{c}{ Independent variable } \\
\hline $\mathrm{X}_{1}$ & Regression equation & S.E. & $\mathrm{R}^{2}$ \\
\hline Ears/plant & $\mathrm{Y}=-11.31+74.29 \mathrm{X}_{1}$ & 4.54 & 58.55 \\
Ear diameter & $\mathrm{Y}=-52.68+22.58 \mathrm{X}_{2}$ & 3.91 & 14.95 \\
Kernels/row & $\mathrm{Y}=\mathrm{Y}=-33.73+2.43 \mathrm{X}_{3}$ & 0.22 & 38.95 \\
$\begin{array}{c}\text { 100 kernel } \\
\text { weight }\end{array}$ & $\mathrm{Y}=-42.27+3.31 \mathrm{X}_{4}$ & 0.34 & 33.17 \\
\hline
\end{tabular}

$\mathrm{Y}=-86.10+58.05 \mathrm{X}_{1}+9.27 \mathrm{X}_{2}+0.54 \mathrm{X}_{3}+1.188 \mathrm{X}_{4} ; \mathrm{R}^{2}=72.41 \%$

Stepwise regression analysis showed ears per plant to be the most important yield component under Striga infestation $\left(\mathrm{R}^{2}=0.58\right)$, followed by kernels per row $\left(\mathrm{R}^{2}=0.38\right)$ (Table 6). This indicates that yield differences under Striga could be explained by variation in ears per plant and kernels per row. The overwhelming proportion of yield variation accounted by ears per plant shows that this trait was a major yield component under Striga, and it could be useful as a selection index.

\section{Discussion}

\subsection{Striga Emergence}

The lower levels of Striga infestation under maize stover (30 kg N ha $\left.{ }^{-1}\right)$ combined with urea $\left(45 \mathrm{~kg} \mathrm{~N} \mathrm{ha}^{-1}\right)$ and Calliandra $\left(45 \mathrm{~kg} \mathrm{~N} \mathrm{ha}^{-1}\right)$ combined with urea $\left(30 \mathrm{~kg} \mathrm{~N} \mathrm{ha}^{-1}\right)$ could be attributed to higher mineral $\mathrm{N}$ levels that was provided by these treatments. High $\mathrm{N}$ levels have been reported to lead to a decrease in Striga infestation and an increase in crop yields [20]. Many scientists however, link the effect of nitrogen to delayed germination of the Striga seed, reduced radicle elongation, reduced production of Striga stimulant by the host plant and reduction of seeds response to the stimulants [21]. Higher densities of Striga in the control and sole maize stover may be attributed to low nitrogen levels in these treatments. Striga damage has been observed to be more pronounced in host plants grown in $\mathrm{N}$ deficient soils compared to those grown in soils well supplied with nitrogen [22]. Host plants produced in environments that are low in $\mathrm{N}$ produce higher levels of the Striga stimulant leading to higher Striga germination [23].

\subsection{Ear Traits}

Although ears per plant is known to be a genetically controlled characteristic [24], this trait was also influenced by nutrient availability. The higher ear per pant under maize stover (30 kg N ha ${ }^{-1}$ ) combined with urea (45 kg N $\mathrm{ha}^{-1}$ ) was mainly influenced by higher soil mineral $\mathrm{N}$ levels, while the control recorded low measures due to low soil nutrients. Low numbers of ears per plant may also be attributed to higher Striga numbers in the control and sole maize stover treatments (Table 3 ). This does suggest that Striga effects on maize grain yield relate more to pre-than post-flowering stress. Ear reduction from pre-flowering stress results from cessation of ear development and ear abortion [25]. This is in contrast to insidious and more delayed pathogenic effects, which have little or no effect on ears per plant [26].

The higher ear length in the above soil fertility management applications might be attributed to good photo assimilate supply. The maximum assimilate supply should be available during maize grain filling [27]. The two to three-week period after $50 \%$ silking is a critical stage in maize development that is highly dependent on assimilate supply; the period when final kernel number is determined [28]. Hussaini, [29] reported similar response where they linked this significant increase in yield to favorable effect of nitrogen on cob length and cob diameter, factors that are known have direct bearing on the final grain yield.

\subsection{Kernel Traits and Grain Yields}

\subsubsection{Number of grains per row}

Kernels per ear is a product of rows per ear and kernel per row [30]. Since rows per ear is largely genetically controlled [31], variation in the number of kernels per ear would be expected to be largely due to differences in number of kernels per row. Earlier studies have shown that ear length is highly correlated with kernels per row studies [32]. However, a greater number of grains per ear observed under higher $\mathrm{N}$ rates might have resulted from the greater assimilates partitioning to the seeds as a result of a longer growth period and higher photosynthate availability during grain filling period [33]. A decrease in number of grains per ear under low $\mathrm{N}$ application might be attributed to poor development of the sinks and reduced translocation of the photosynthate [34].

\subsection{Maize Grain Yields}

The higher grain yields and 100-grain weight realized under Calliandra $\left(45 \mathrm{~kg} \mathrm{~N}^{-1}\right)$ combined with urea (30 kg $\mathrm{N} \mathrm{ha}^{-1}$ ) and Calliandra $\left(30 \mathrm{Kg} \mathrm{N} \mathrm{ha}^{-1}\right)$ combined with urea $\left(45 \mathrm{~kg} \mathrm{~N} \mathrm{ha}^{-1}\right.$ ) or maize stover (45 $\mathrm{kg} \mathrm{N} \mathrm{ha}^{-1}$ ) combined with urea (30 $\left.\mathrm{kg} \mathrm{N} \mathrm{ha}^{-1}\right)$ and maize stover at $\left(30 \mathrm{~kg} \mathrm{~N} \mathrm{ha}^{-1}\right)$ combined with urea ( $45 \mathrm{Kg} \mathrm{N} \mathrm{ha}^{-1}$ ), is mainly attributed to high mineral $\mathrm{N}$ levels in these treatments. Higher nitrogen content facilitates chlorophyll formation, photosynthesis, assimilate production and higher partitioning of dry matter to ears that resulted in optimum production of yield components which have direct bearing on the final grain yield. Hussaini, [29], reported similar response where they attributed this significant increase in yield to favourable effect of nitrogen on cob length and cob diameter, which all have direct bearing on the final grain yield. The increase in yield could be a result of good dry matter production for 
grain filling mostly attributed to a higher photosynthetic area provided by the leaves.

The low grain yields in sole maize stover treatments and the control could be attributed to low mineral nitrogen levels under these treatments (Table 3). Low quality organic materials such as maize stover with high $\mathrm{C} / \mathrm{N}$ ratio (70) take long to decompose and release $\mathrm{N}$ leading to $\mathrm{N}$ immobilization [35]. Low maize yields may also be attributed to high levels of Striga infestation under these treatments (Table 3). Yield reduction from Striga infestation result from a series of physiological changes in the host plants following Striga parasitism. These include weakening of the host, wounding of its outer root tissues and absorption of moisture, photosynthates and minerals [36]. Apart from parasitism, Striga impairs photosynthetic efficiency [37] and exerts toxic or phytotoxic effects [38].

\subsection{Relationship between Maize Grain Yield and Yield Components}

The increase in grain yield results from beneficial influence of yield contributing characters and the positive interaction of nutrients in the blended fertilizer. The association of grain yield with number of kernels per row observed in this study agreed [39], who concluded that increasing the number of kernels per row contributes to an increase in maize grain yield. The strong relationships between grain yield and number of kernels per row and between grain yield and 100 kernels weight were also in agreement with the findings [40] indicating that these two yield attributes are the most important components directly related to grain yield in maize. Similarly, a strong positive association of maize grain yield with number of kernels per row [41].

\section{Conclusions and Recommendations}

All the three ear traits (ears per plant, ear length, and ears diameter) were significantly higher under Calliandra (45 $\mathrm{kg} \mathrm{N} \mathrm{ha}{ }^{-1}$ ) combined with urea (30 $\mathrm{kg} \mathrm{N} \mathrm{ha}^{-1}$ ) and Calliandra at (30 Kg N ha $\left.{ }^{-1}\right)$ combined with urea $(45 \mathrm{~kg} \mathrm{~N}$ $\left.\mathrm{ha}^{-1}\right)$ or maize stover $\left(45 \mathrm{~kg} \mathrm{~N} \mathrm{ha}^{-1}\right)$ combined with urea (30 $\mathrm{kg} \mathrm{N} \mathrm{ha}{ }^{-1}$ ) and maize stover at (30 $\mathrm{kg} \mathrm{N} \mathrm{ha}^{-1}$ ) combined with urea (45 $\left.\mathrm{kg} \mathrm{N} \mathrm{ha}^{-1}\right)$. Early and consistent supply of nitrogen is critical for production of maize under Striga infested conditions. Number of ears per plant was a major yield component and accounted for $\left(\mathrm{R}^{2}=0.74\right)$ of the variation in grain yield under Striga.

\section{REFERENCES}

[1] Gethi, J. G., Smith, S. E., Mitchell, S. E., \& Kresovich, S. Genetic diversity of Striga hermonthica and Striga asiatica population in Kenya. Weed Research, 45, 64-73, 2005.
[2] De Groote, H., Wangare, L., Kanampiu, F., Odendo, M. Diallo, A., Karaya, H., \& Friesen, D. The potential of herbicide resistant maize technology for Striga control in Africa. Elsevier, Kenya. 2007.

[3] Aliyu, L., Lagoke, S. T. O., Carsky, R. I., Kling, J., Omotayo, O., \& Shebayan, J. Y. Technical and economic evaluation of some Striga control packages in maize in the northern Guinea savanna (p. 66). Elsevier Ltd. 2004.

[4] Ejeta, G. The Striga scourge in Africa: A growing pandemic. In G. Ejeta \& J. Gressel (Eds.), Integrating New Technologies for Striga Control (pp. 3-16). World Scientific Conference, Singapore. 2007.

[5] Khan, Z. R., Pickett, J. A., Wadhams, L. J., Hassanali, A., \& Midega, C. A. O. Combined control of Striga hermonthica and stemborers by maize-Desmodium spp. intercrops. Crop Protection, 25, 989-995, 2006.

[6] Venne, J., Beed, F., Avocanh, A., \& Watson, A. Integrating Fusarium oxysporum f.sp strigae into cereal cropping systems in Africa. Pest Management Science, 65, 572-580, 2009.

[7] Cambridge Economic Policy Associates (CEPA). Business Plan: Striga control in Africa. London, UK, 2004

[8] Woomer, P.L. and Savala, C.E.N. Mobilizing Striga control technologies in Kenya. African Crop Science Conference Proceedings 9: 677-681, 2009.

[9] Woomer PL, Savala CEN. Mobilizing Striga control technologies in Kenya. African Crop Science Conference Proceedings: 9: 677-681, 2009.

[10] Vanlauwe, B., Kanampiu, F., Odhiambo, G.D., De Groote, H., Wadhams, L.J., Khan, Z.R. Integrated management of Striga hermonthica, stem borers, and declining soil fertility in western Kenya. Field Crops Research 107, 102-115, 2008.

[11] MacOpiyo, L., Vitale, J., \& Sanders, J. An ex-ante assessment of a Striga control programme in East Africa. Kilimo Trust (pp. 6-25), 2010.

[12] Kim, S.K., Adetimirin, V.O. C. T. and Dossou, R. Yield losses in maize due to Striga hermonthica in West and Central Africa. International Journal of Pest Management 48:211-217, 2002.

[13] Midega, C.A.O., Wasonga, C.J., Hooper, A.M., Pickett, J.A. and Khan, Z.R. Drought-tolerant Desmodium species effectively suppress parasitic Striga weed and improve cereal grain yields in western Kenya. Crop Protection 98: 94-101, 2017.

[14] Lendzemo, V.W., Kuyper, Th. W., Kropff, M.J., van Ast, A. van. Field inoculation with arbuscular mycorrhizal fungi reduces Striga hermonthica performance on cereal crops and has the potential to contribute to integrated Striga management. Field Crops Research 91, 51-61, 2005.

[15] Tittonell P, Vanlauwe B, Leffelar P A, Lowe E, and Giller, K.E. Exploring diversity in soil fertility management of smallholder farms in western Kenya. I. heterogeneity at regional and farm scale. Agriculture, Ecosystems and Environment; 110:149-165, 2005.

[16] Vanlauwe, B., Tittonell, P. and Mukalama, J. Within farm soil fertility gradients affect response of maize to fertilizer 
application in western Kenya. Nutrient cycling in Agroecosystems 76:171-182, 2006.

[17] Bationo A., Mokwunye U., Vlek P.L.G., Koala S. and Shapiro B.I. Soil fertility management for sustainable land use in the West African Sudano-Sahelian zone. In: Soil Fertility Management in Africa: A regional Perspective. Academy Science Publisher \& Tropical Soil Biology and Fertility. pp 253-292, 2003.

[18] Jaetzold, R., Schmidt, H., Hornetz, B., Shisanya, C. Farm Management Handbook of Kenya. Ministry of Agriculture/GTZ, Nairobi. 2006.

[19] Kim, S. K. Genetics of maize tolerance of Striga hermonthica. Crop Science 34, 900-907, 1994.

[20] Kiwia A, Imo M, Jama B, Okalebo JR. Coppicing improved fallows are profitable for maize production in Striga infested soils of western Kenya. Agroforestry Systems. 76:455-465, 2009.

[21] Hassan MM, Abdelgain EM, Babiker AGT. Potential Bacterial Strains and Nitrogen in reduction of Striga hermonthica (Del.) Benth. Infesting sorghum. America Eurasian Journal of Sustainable Agriculture. 3(1): 1-9, 2009.

[22] Menkir A, Kling J. Response to recurrent selection for resistance to Striga hermonthica (Del.) Benth in a tropical maize production. Crop Science. 47:674-682, 2007.

[23] Cechin I, Press MC. Nitrogen relations of the sorghum-Striga hermonthica host parasite association: Growth and photosynthesis. Plant, Cell and Environment. 16: 237-247, 1993.

[24] Wajid, A., A. Ghaffar, M. Maqsood, K. Hussain and W. Nasim. Yield response of maize hybrids to varying nitrogen rates. Pak. J. Agric. Sci. 44(2): 217-220, 2007.

[25] Jacobs, B.C. and Pearson, C.J. Pre-flowering growth and development of the inflorescences of maize: II. Accumulation and partitioning of dry matter and nitrogen by inflorescences. Journal of Experimental Botany, Volume 43, Issue 4, April 1992, Pages 565-569, 1991.

[26] Kim, S.K., and Brewbaker, J.L. Effects of Puccinia sorghi rust and several yield agronomic traits of maize in Hawaii. Crop Science 16: 874-877, 1976.

[27] Arif, M., I. Amin, M. T. Jan, I. Munir, K. Nawab, N. U. Khan, and K. B. Marwat. Effect of Plant Population and Nitrogen Levels and Methods of Application on Ear Characters and Yield of Maize. Pakistan Journal of Botany, 42 (3): 1959-1967, 2010.

[28] Haney, R. L., Haney, E. B., Smith, D. R. and White, M. J. Estimating Potential Nitrogen Mineralization Using the Solvita Soil Respiration System. Open Journal of Soil Science, 5, (53) 319-323, 2015.

[29] Hussaini, M.A., Ogunlela, V.B., Ramalan, A.A. and Falaki, A.M. Growth and development of maize (Zea mays L.) in response to different levels of nitrogen, phosphorus and irrigation. Crop Research 22 (2): 141-149, 2001.

[30] Abendroth, L.J., Elmore, R.W., Boyer, M.J., and Marlay, S.K. Corn Growth and Development. PMR 1009. IOWA State Univ. Ext., Ames, I. A. 2011.

[31] Roy, S.K., and Biswas, P.K. Effect of plant density and detopping following silking on cob growth, fodder and grain yield of maize (Zea mays). The Journal of Agricultural Science 119(03), 1992.

[32] Bavec F., Bavec M. Effect of plant population on leaf area index, cob characteristics and grain yield of early maturing maize cultivars (FAO 100-400). Eur. J. Agric., 16: 151-159. 2002.

[33] Amanullah, M.A., Sukhdev, S.M., and Riaz, A.K. Effects of Phosphorus Fertilizers Source and Plant Density on Growth and Yield of Maize in Northwestern Pakistan. Journal of Plant Nutrition. 32:12, 2080-2093, 2009.

[34] Dawadi, D.R. and Sah, S.K. Growth and Yield of Hybrid Maize (Zea mays L.) in Relation to Planting Density and Nitrogen Levels during Einter Season in Nepal. Tropical Agricultural Research Vol 23 (3):218-227, 2012.

[35] Palm C.A, Gachengo C.N., Delve R.J, Cadisch G., Giller K.E. Organic inputs for soil fertility management in tropical agroecostystems: application, of an organic resource data base. Agriculture, Ecosystems and Environment: 83: 27-42, 2001.

[36] Tenebe, V.A., and Kamara, H. M. Effect of Striga hermonthica on growth characteristics of sorghum intercropped with ground nut varieties. J. Agronomy and Crop science, 188, 376-381, 2002.

[37] Stewart, G. R., Press, M.C., Graves, J.D., Nour, J.J. and Wylde, A. A physiological characterization of the host-parasite association between sorghum bicolor and Striga hermonthica and its implication for striga control. In: Combating Striga in Africa (Ed.S. K. Kim), pp. 48-54. Ibadan, Nigeria: International Institute of Tropical Agriculture.1991.

[38] Gurney A.l, Slate J, Press M.C, Scholes J.D. A novel form of resistance in rice to angiosperm parasite Striga hermonthica. New Phytologist. 169:199-208, 2006.

[39] Jugenheimer, R. W. Corn: improvement, seed production and uses. Robert E. Krieger publishing company, Malabar, Florida. 749 p. 1985.

[40] Khatun, F., S. Begum, A. Mothin, S. Yasmin and M.R. Islam. Correlation coefficient and path analysis of some maize hybrids. Bangladesh. J. Botany: 28 (1): 9-15, 1999.

[41] Elings, A., J. White and G. O. Edmeades, Modeling tropical maize under drought and low N. Agronomy Abstracts, 1996 Annual Meeting, Indianapolis, Indiana, November 3-8, 1996. Madison, Wisconsin, USA: American Society of Agronomy. 1996. 